\title{
Response of Some Landrace Rice (Oryza sativa L.) Cultivars to Applied Nitrogen in Lowland Ecosystem
}

\author{
M. A. A. Mamun*, M. M. Haque, Q. A. Khaliq, M. A. Karim and A. J. M. S. Karim \\ Bangabandhu Sheikh Mujibur Rahman Agricultural University, Gazipur-1706, Bangladesh. \\ *Corresponding author and Email: aamamunbrri@yahoo.com
}

Received: 3 April $2018 \quad$ Accepted: 23 June 2018

\begin{abstract}
An experiment was conducted to determine the effects of nitrogen $(\mathrm{N})$ fertilization on growth and yield of some landrace rice (Oryza sativa L.) cultivars in lowland ecosystem. Three popular landrace rice cultivars: Rajashail, Kutiagni and Sadamota were treated with five times of $\mathrm{N}$ application viz. (i) two split applications of prilled urea (PU) at 10 days after transplanting (DAT) and before panicle initiation (PI) stage, (ii) deep placement of urea super granule (DPUSG) at 10 DAT, (iii) DPUSG before PI stage, (iv) PU application before PI stage and (v) control. The results showed that the landrace rice cultivar Kutiagni had the highest number of tillers under PU, while Rajashail gave the highest number of tillers under DPUSG applied before PI stage. Further, Kutiagni produced higher amount of dry matter under two splits of PU, while Rajashail produced higher amount of dry matter under DPUSG applied before PI stage. However, application of PU before PI stage significantly increased leaf area index in all the three landraces. The varieties responded to applied $\mathrm{N}$ and produced the highest yield in Kutiagni. The DPUSG at 10 DAT increased straw yield but failed to increase grain yield even over control. The DPUSG before PI stage significantly increased rice yield and economic return. The yield of rice in DPUSG applied before PI stage was comparable to two splits of PU and top dressing of PU before PI stage. Compared to control $\left(2.93 \mathrm{t} \mathrm{ha}^{-1}\right)$, yield increase was $26 \%$ in Kutiagni $\left(3.70 \mathrm{t} \mathrm{ha}^{-1}\right)$ under DPUSG before PI stage. These results suggest that Kutiagni was more responsive to added N and this cultivar could be cultivated with DPUSG at PI stage.
\end{abstract}

Keywords: Landrace, nitrogen, lowland ecosystem, rice, yield response.

\section{Introduction}

Rice (Oryza sativa L.) is the common food for more than half of the world population (IRRI, 2013) and it covers 158 million ha of land which produces 490 million tons of milled rice (FAO, 2016). In Bangladesh, rice is the staple food crop and it occupies about $75 \%$ of the cropped areas (BBS, 2015). There are three distinct rice growing seasons in Bangladesh like Aus (cultivated during March to June), Aman (during July to December) and Boro (during January to June). Aman rice is generally grown under rainfed condition. Although, there are some scope for extending modern varieties under rainfed condition but nearly $28 \%$ of rice area is still occupied by landraces adaptable to the specific ecosystem (land type, hydrological condition and low nutrient status) of the country (Bhuiyan et al., 2002). 
Yield potential of the landraces are however, poor because most of the cultivars are lodging susceptible and non-responsive to high input (Hamid et al., 2004). Thus, yield improvement of the landraces is difficult due to limited application of $\mathrm{N}$, which is considered as the most important plant nutrient for rice throughout the world (Lin et al., 2006). Nitrogen improves crop growth and yield through expansion of leaf area, increases the number of spikelets per panicle, filled grains per panicle and grain $\mathrm{N}$ content (Dobermann and Fairhurst, 2000). Generally, the effective use of $\mathrm{N}$ in a cropping system depends on adequate rate, suitable source and application time (Fageria et al., 2006). Proper N utilization can improve $\mathrm{N}$ uptake and photosynthetic rate, delay in leaf senescence and increase in amount of dry matter for grain filling which may improve the productivity of rice.

However, timing of $\mathrm{N}$ application is very important for landraces and $\mathrm{N}$ content of soil is low where the landraces are cultivated (Mamun et al., 2015). Application of $\mathrm{N}$ at early growing stage mainly contributes to the vegetative development, makes plant bushy and induces lodging. Application of $\mathrm{N}$ at mid-tillering stage could be attributed to high losses of $\mathrm{N}$ through denitrification, as the plants are not big enough to absorb applied $\mathrm{N}$ due to their small root mass (Miah et al., 2016). As the landraces are susceptible to lodging and this problem is accelerated with the applied $\mathrm{N}$, it is imperative to examine the amount and time of $\mathrm{N}$ fertilization so that yield improvement of landraces can be done by addressing the problem of lodging. Thus, a suitable $\mathrm{N}$ management technique is vital which will increase grain fertility, reduce spikelet sterility and improve rice grain yield. Top dressing of prilled urea and deep placement of urea super granule (USG) are the forms of urea fertilization in Bangladesh. Top dressing of prilled urea is very much popular in rice cultivation all over the country, except in the tidal flood-affected areas. In tidal flooded areas, surface application of $\mathrm{N}$ fertilizer like prilled urea is not possible due to high risk of surface loss (Rochette et al., 2013).
In contrast, deep placement of urea reduces $\mathrm{N}$ concentration in the floodwater; thus, it reduces $\mathrm{N}$ loss and increases uptake by the rice plant. Deep placement of urea increases $\mathrm{N}$ use efficiency up to 50 to $70 \%$, increase grain yield by 15 to $20 \%$, and reduces the fertilizer $\mathrm{N}$ use by 30 to $40 \%$ (IFDC, 2013). The present study was therefore, conducted to investigate the influence of $\mathrm{N}$ fertilizer application on the growth and yield of some landrace rice cultivars in lowland ecosystem.

\section{Materials and Methods}

The experiment was conducted under lowland ecosystem of Bangabandhu Sheikh Mujibur Rahman Agricultural University, Gazipur $\left(24^{\circ} 09^{\prime} \mathrm{N}\right.$ latitude, $90^{\circ} 26^{\prime} \mathrm{E}$ longitudes), Bangladesh during the rainy season of 2015. The experimental site was characterized by heavy rainfall through out the rice-growing season. The soil of the experimental plot was a silty clay, which contains $\mathrm{N}$ of $0.09 \%, \mathrm{P}$ of $8 \mathrm{ppm}, \mathrm{K}$ of $0.29 \mathrm{meq} / 100 \mathrm{~g}$ soil, $\mathrm{S}$ of $15 \mathrm{ppm}$ and $\mathrm{Zn}$ of 0.7 ppm. The experiment was carried out in a splitplot design with three replications. The treatments included three popular rice landraces placed in the main plot and five times of $\mathrm{N}$ application placed in sub-plot. The landraces were Rajashail, Kutiagni, Sadamota, and the five times of $\mathrm{N}$ applications were: (i) two splits of prilled urea (PU) applied at 10 days after transplanting (DAT) and before panicle initiation (PI) stage; (ii) Deep placement of urea super granule (DPUSG) at $10 \mathrm{DAT}$; (iii) DPUSG before PI stage; (iv) PU applied before PI stage; and (v) no urea (control). Nitrogen was applied at the rate of $30 \mathrm{~kg} \mathrm{~N} \mathrm{ha}^{-1}$ in the form of prilled urea (PU) and urea super granule (USG - $1.8 \mathrm{~g}$ each ball). A blanket dose of fertilizers of 7-15$7-1 \mathrm{~kg}$ P-K-S-Zn ha ${ }^{-1}$ was applied in $3 \mathrm{~m} \times 3 \mathrm{~m}$ plots and was thoroughly incorporated into the soil during final land preparation. Twenty six day-old seedlings were transplanted on 4 August 2015 in $30 \mathrm{~cm} \times 30 \mathrm{~cm}$ spacing. The crop was adequately protected from weed, diseases and pests throughout the growing season. 
At heading stage, tiller number, leaf area index and dry matter production were determined. Yield and yield components were recorded during harvesting. The panicle density was determined from 16 hills before harvest collected from each plot. The number of grains per panicle was counted and 1000-grain weight was determined from 10 randomly sampled panicles per plot. The grains were separated and counted following standard procedures. Rice grain and straw yields were determined by harvesting $5 \mathrm{~m}^{2}$ areas from the middle of each plot. The grains were sun dried and winnowed before weighing and yield was converted into $\mathrm{t} \mathrm{ha}^{-1}$. The grain yield was adjusted to $14 \%$ moisture content using the following formula:

$$
\text { Adjusted weight }=\frac{\mathrm{W} \times\left(100-\mathrm{M}_{1}\right)}{\left(100-\mathrm{M}_{2}\right)} \times 100
$$

Where, $\mathrm{W}$ is the fresh weight; and $\mathrm{M}_{1}$ and $\mathrm{M}_{2}$ were the fresh and adjusted moisture percents of the grain, respectively. Harvest index (HI) was computed as:

$$
\begin{gathered}
\text { Harvest index }(\%)=\text { - -----------------× } \times 100 \\
\text { Grain yield }+ \text { Straw yield }
\end{gathered}
$$

Grain and straw $\mathrm{N}$ concentration was determined from the collected plant samples. The samples were dried at $70^{\circ} \mathrm{C}$ for $72 \mathrm{hrs}$ and ground. The ground sample was digested in concentrated $\mathrm{H}_{2} \mathrm{PO}_{4}$ and total $\mathrm{N}$ concentration was determined by micro Kjeldahl method. Nitrogen uptake by grain and straw were determined as:

$\mathrm{N}$ accumulation in grain $\left(\mathrm{kg} \mathrm{ha}^{-1}\right)=$

$\% \mathrm{~N}$ in grain $\times$ oven dried grain yield $\left(\mathrm{kg} \mathrm{ha}^{-1}\right)$

100

$\mathrm{N}$ accumulation in straw $\left(\mathrm{kg} \mathrm{ha}^{-1}\right)=$

$\% \mathrm{~N}$ in straw $\times$ oven dried straw yield $\left(\mathrm{kg} \mathrm{ha}^{-1}\right)$
Total $\mathrm{N}$ accumulation $\left(\mathrm{kg} \mathrm{ha}^{-1}\right)=\mathrm{N}$ accumulation in grain $+\mathrm{N}$ accumulation in straw

Nitrogen harvest index $(\%)=$

$\mathrm{N}$ accumulation in grain

Total N accumulation

The profit from nitrogen $(\mathrm{N})$ fertilization were determined based on: price of $\mathrm{N}\left(\mathrm{BDT} \mathrm{ha}^{-1}\right)$; additional labor cost for urea application; additional grain yield ( $\Delta$ Grain yield) was calculated as the yield difference between $\mathrm{N}$ applied plots and no urea applied plot. Net profit ( $\Delta$ Profit) was calculated as the profit difference between $\mathrm{N}$ applied plot yield and no urea applied plot. The local market price of nitrogen fertilizer and rice were considered.

$\Delta$ Grain yield $\left(\mathrm{kg} \mathrm{ha}^{-1}\right)=$ Grain yield of $\mathrm{N}$ applied plot - grain yield of no urea applied plot

Gross margin $\left(\right.$ BDT ha $\left.{ }^{-1}\right)=\Delta$ Grain yield $(\mathrm{kg} \mathrm{ha}$ $\left.{ }^{1}\right) \times$ Price of rice $\left(\mathrm{BDT} \mathrm{kg}^{-1}\right)$

Total cost for $\mathrm{N}\left(\mathrm{BDT} \mathrm{ha}^{-1}\right)=$ Includes price of $\mathrm{N}$ + labor cost for urea application

Profit over $\mathrm{N}$ cost $\left(\mathrm{BDT} \mathrm{ha}^{-1}\right)=$ Gross margin from urea application - Cost for $\mathrm{N}$

The collected data were analyzed using a computer software package Crop Stat, version 7.2 (IRRI, 2007). Treatment means were separated with least significant difference (LSD) at the 5\% level of probability (Gomez and Gomez, 1984). Graphical analyses were done using Excel software (Microsoft Corporation, Redmond, WA, USA).

\section{Results and Discussion}

\subsection{Growth parameters}

Applied $\mathrm{N}$ fertilizer exerted significant effects on tillers and dry matter production of landrace rice cultivars Rajashail and Kutiagni but not on Sadamota (Table 1). However, all the landrace rice cultivars were not equally responsive to added $\mathrm{N}$ fertilizer. Rajashail produced the highest number of tillers $\left(269 \mathrm{~m}^{-2}\right)$ and dry 
matter $\left(715 \mathrm{~g} \mathrm{~m}^{-2}\right)$ under deep placement of urea super granule (DPUSG) before panicle initiation (PI) followed by prilled urea (PU) application before PI stage. Similarly, the highest number of tillers $\left(296 \mathrm{~m}^{-2}\right)$ and dry mass $\left(898 \mathrm{~g} \mathrm{~m}^{-2}\right)$ of Kutiagni was recorded in DPUSG at 10 DAT and two splits of PU, respectively. The control treatment showed the lowest number of tillers and dry mass in both cultivars. The leaf area index (LAI) of rice cultivars was also differed statistically due to $\mathrm{N}$ fertilization. The LAI of Rajashail (4.99), Kutiagni (5.13) and Sadamota (5.10) was the highest with PU before PI followed by DPUSG before PI stage. The control treatment produced the lowest LAI in all cultivars (Table 1). Higher number of tillers and increased dry matter production of the rice cultivars (Table 1) may be due to increase in LAI with the application $\mathrm{N}$ before PI stage. Higher LAI indicates better leaf expansion and canopy structure which attributed to greater interception of solar radiation to produce higher amount of dry matter. The DPUSG at later growth stage of rice ensure continuous supply of $\mathrm{N}$ to the crop that helps the leaves to stay green for longer time. Nitrogen is a component of cholorophyll (photosynthetic molecule) and essential for many enzymatic functions in the plant body (Fageria, 2014). Application of $\mathrm{N}$ at PI stage showed better LAI and higher leaf cholorophyll content also reported by Bah et al. (2009). The authors reported that $\mathrm{N}$ fertilizer increased leaf expansion rate, leading to intercept more solar radiation by the crop canopy and enhanced dry matter production. Further, applied $\mathrm{N}$ increased cell division resulting taller plant and production of more tiller of rice (Chaturvedi, 2005). Dobermann et al. (2002) stated that application of $\mathrm{N}$ fertilizer before or at PI stage helped produce higher leaf, stem and panicle biomass that lead to increase plant dry matter content.

\subsection{Yield components and grain yield}

Interaction of $\mathrm{N}$ fertilizer with landrace rice cultivars demonstrated a significant effect on panicle production of landrace rice cultivars (Table 2). The variety Rajashail produced the highest number of panicles $\mathrm{m}^{-2}$ under DPUSG at 10 DAT which was statistically similar with that of other treatments. In case of Kutiagni, maximum number of panicles $\mathrm{m}^{-2}$ was recorded from application of PU before PI followed by DPUSG at 10 DAT. The cultivar Sadamota produced higher number of panicles $\mathrm{m}^{-2}$ with the application of PU before PI. For all varieties, control (no urea-applied plots) produced the lowest number of panicles $\mathrm{m}^{-2}$. Number of panicles per unit area is the most important yield contributing trait which can be manipulated significantly with the $\mathrm{N}$ fertilization application at an appropriate growth stage during the crop growth cycle. Nitrogen applied late during the reproductive growth stage could be absorbed by the crop (Fageria and Baligar, 1999).

Table 1. Effect of $\mathrm{N}$ fertilization on growth parameters at heading of landrace rice cultivars

\begin{tabular}{|c|c|c|c|c|c|c|c|c|c|}
\hline \multirow[b]{2}{*}{$\begin{array}{l}\text { Nitrogen } \\
\text { fertilization }\end{array}$} & \multicolumn{3}{|c|}{ Tillers (no. $\mathrm{m}^{-2}$ ) } & \multicolumn{3}{|c|}{ Dry matter $\left(\mathrm{g} \mathrm{m}^{-2}\right)$} & \multicolumn{3}{|c|}{ Leaf area index } \\
\hline & $\begin{array}{l}\text { Raja } \\
\text { shail }\end{array}$ & $\begin{array}{c}\text { Kutia } \\
\text { gni }\end{array}$ & $\begin{array}{l}\text { Sada } \\
\text { mota }\end{array}$ & $\begin{array}{l}\text { Raja } \\
\text { shail }\end{array}$ & $\begin{array}{c}\text { Kutia } \\
\text { gni }\end{array}$ & $\begin{array}{l}\text { Sada } \\
\text { mota }\end{array}$ & $\begin{array}{l}\text { Raja } \\
\text { shail }\end{array}$ & $\begin{array}{c}\text { Kutia } \\
\text { gni }\end{array}$ & $\begin{array}{l}\text { Sada } \\
\text { mota }\end{array}$ \\
\hline Two splits of PU & 232 & 279 & 216 & 509 & 898 & 752 & 4.18 & 4.17 & 4.32 \\
\hline DPUSG at 10 DAT & 238 & 296 & 231 & 561 & 805 & 804 & 3.87 & 4.02 & 4.10 \\
\hline DPUSG before PI & 269 & 261 & 197 & 715 & 733 & 911 & 4.55 & 4.64 & 4.60 \\
\hline PU before PI & 242 & 289 & 184 & 632 & 767 & 807 & 4.99 & 5.13 & 5.10 \\
\hline No urea & 199 & 247 & 203 & 483 & 741 & 805 & 3.02 & 3.12 & 3.30 \\
\hline $\mathrm{LSD}_{0.05}$ for $\mathrm{N}$ & 46 & 30 & NS & 154 & 147 & NS & 0.87 & 0.12 & 0.33 \\
\hline $\mathrm{N} \times$ Variety & & 38 & & & 188.95 & & & 0.20 & \\
\hline $\mathrm{CV}(\%)$ & & 9.3 & & & 15.2 & & & 2.8 & \\
\hline
\end{tabular}

PU = Prilled urea, DPUSG = deep placement of urea super granule, DAT = Days after transplanting, $\mathrm{PI}=$ Panicle initiation and NS $=$ Not significant 
Table 2. Effect of $\mathrm{N}$ fertilization on yield components of landrace rice cultivars at harvest

\begin{tabular}{|c|c|c|c|c|c|c|c|c|c|}
\hline \multirow{2}{*}{$\begin{array}{l}\text { Nitrogen } \\
\text { fertilization }\end{array}$} & \multicolumn{3}{|c|}{ Panicles $\mathrm{m}^{-2}$ (no.) } & \multicolumn{3}{|c|}{ Grain yield $\left(\mathrm{t} \mathrm{ha}^{-1}\right)$} & \multicolumn{3}{|c|}{ Harvest index (\%) } \\
\hline & $\begin{array}{l}\text { Raja } \\
\text { shail }\end{array}$ & $\begin{array}{l}\text { Kuti } \\
\text { agni }\end{array}$ & $\begin{array}{l}\text { Sada } \\
\text { mota }\end{array}$ & $\begin{array}{l}\text { Raja } \\
\text { shail }\end{array}$ & $\begin{array}{l}\text { Kuti } \\
\text { agni }\end{array}$ & $\begin{array}{l}\text { Sada } \\
\text { mota }\end{array}$ & $\begin{array}{l}\text { Raja } \\
\text { shail }\end{array}$ & $\begin{array}{l}\text { Kuti } \\
\text { agni }\end{array}$ & $\begin{array}{l}\text { Sada } \\
\text { mota }\end{array}$ \\
\hline Two splits of PU & 200 & 191 & 144 & 2.90 & 3.61 & 3.22 & 43 & 39 & 38 \\
\hline DPUSG at $10 \mathrm{DAT}$ & 219 & 206 & 142 & 2.70 & 3.21 & 2.75 & 41 & 40 & 34 \\
\hline DPUSG before PI & 206 & 189 & 137 & 3.09 & 3.70 & 3.08 & 45 & 42 & 38 \\
\hline PU before PI & 212 & 218 & 163 & 2.79 & 3.44 & 3.22 & 41 & 35 & 36 \\
\hline No urea & 190 & 188 & 135 & 2.65 & 2.93 & 2.54 & 45 & 38 & 37 \\
\hline $\mathrm{LSD}_{0.05}$ for $\mathrm{N}$ & NS & NS & NS & NS & 0.28 & NS & NS & 4.56 & NS \\
\hline $\mathrm{N} \times$ Variety & & 35.85 & & & 0.48 & & & 7.28 & \\
\hline $\mathrm{CV}(\%)$ & & 11.5 & & & 9.2 & & & 10.08 & \\
\hline
\end{tabular}

PU = Prilled urea, DPUSG = deep placement of urea super granule, DAT = Days after transplanting, PI $=$ Panicle initiation and NS $=$ Not significant

The $\mathrm{N}$ fertilization and cultivar interacted significantly to influence grain yield. Similarly, $\mathrm{N}$ fertilization exerted a significant effect on grain yield of Kutiagni (Table 2). The cultivar Kutiagni produced the highest grain yield (3.70 t $\mathrm{ha}^{-1}$ ) in DPUSG before PI treatment. The second highest grain yield $\left(3.61 \mathrm{t} \mathrm{ha}^{-1}\right)$ was recorded from two splits of PU followed by PU before PI stage. Higher yield of cultivar Kutiagni was attributed due to increase in number of panicles under applied $\mathrm{N}$ through DPUSG before PI stage. In case of Rajashail, numerically higher grain yield obtained from DPUSG before PI which was statistically similar with that in other $\mathrm{N}$ treatments. Sadamota yielded the highest in both two splits of PU and application of PU before PI, which were statistically similar with that in DPUSG before PI treatment. On the other hand, DPUSG at 10 DAT and control plot produced statistically similar grain yields for all varieties. Although two splits of PU and top dressing of PU before PI gave satisfactory yield in all the cultivars, but there is little scope for broadcasting of PU due to surface and volatilization loss through flash flood water under heavy rainfall condition. Although application of DPUSG at 10 DAT produced the highest number of panicles $\mathrm{m}^{-2}$ it gave the lowest grain yield than other treatments in all the cultivars (Table 2). It indicates that the application of $\mathrm{N}$ at early crop growth stage may not be utilized by the grains of landrace rice cultivars because most of the $\mathrm{N}$ contributed to vegetative growth. Thus, the results suggest that the application of $\mathrm{N}$ at later growth stage either as DPUSG or as PU synchronize with the crop demand and making it possible for the plant to translocate more $\mathrm{N}$ to the grain. The application of $\mathrm{N}$ through DPUSG before PI stage increased grain yield at a range between 0.5 to $1.0 \mathrm{t} \mathrm{ha}^{-1}$ (Table 2). However, the grain yield obtained by DPUSG before PI was much higher than that by DPUSG at 10 DAT.

The yield of Kutiagni and Sadamota in DPUSG before PI was comparable with that in two splits of PU and PU before PI. In the present experiments, the improved grain yield with DPUSG before PI stage might be due to production of higher number of panicles $\mathrm{m}^{-2}$ and absorbing more $\mathrm{N}$ at the booting and flowering growth stages of rice (Castillo et al., 1992). Moreover, many earlier studies showed that the yield of rice increased with DPUSG compared to top dressing of urea (Gregory et al., 2010; Bandaogo et al., 2015). However, Abedin et al. (2015) found no significant yield variation with the application of $\mathrm{N}$ in landrace rice. The harvest index (HI) of Kutiagni differed significantly with $\mathrm{N}$ fertilization (Table 2). Kutiagni showed the highest HI (42\%) in DPUSG before PI which was significantly higher than that in PU before PI stage. 


\subsection{Nitrogen uptake}

Nitrogen fertilization exerted significant effect on $\mathrm{N}$ uptake by the grains of Kutiagni and Sadamota (Table 3). The highest amount of N was accumulated by the grains of Kutiagni $\left(36.08 \mathrm{~kg} \mathrm{ha}^{-1}\right)$ and Sadamota $\left(31.55 \mathrm{~kg} \mathrm{ha}^{-1}\right)$ in DPUSG and PU before PI stage, respectively although it was non-significant in case of Rajashail. Considering total $\mathrm{N}$ uptake, the highest amount of $\mathrm{N}$ was taken up by cultivars Rajashail and Kutiagni in DPUSG before PI stage, which was statistically identical with that in two splits of PU. All the landrace rice cultivars accumulated lower amounts of $\mathrm{N}$ in no urea plot. Nitrogen fertilizer application and rice cultivar interacted to influence nitrogen harvest index (NHI) significantly. Similarly, N fertilization also exhibited significant effect on NHI of Kutiagni and Sadamota (Table 3).

The highest NHI of Kutiagni and Sadamota obtained from DPUSG before PI and no urea treatment, respectively. In case of Rajashail, higher NHI recorded from no urea treatment. Nitrogen content of rice cultivars markedly increased with the application of $\mathrm{N}$ fertilizer. Mamun et al. (2016) stated that landrace rice cultivars like Sadamota, Lalmota and Moulta absorbed more amount of $\mathrm{N}$ in $\mathrm{N}$ treated plot. Fageria et al. (2010) also reported that the grain $\mathrm{N}$ concentration was low at low $\mathrm{N}$ level. However, the cultivars accumulated more amount of $\mathrm{N}$ with application of either DPUSG or PU before PI stage. This indicates that the N applied at the later growth stage of rice absorbed by both grain and straw. Application of $\mathrm{N}$ at PI stage helped absorb more $\mathrm{N}$ by the rice plant as reported by other authors (Tylaran et al., 2009; Mamun et al., 2017). Fageria and Baligar (1999) also reported that $\mathrm{N}$ applied during reproductive growth stage absorbed by the crop, which was utilized to improve grain yield. Nitrogen uptake by rice showed a significant linear association with grain yield (Figures 2 and 3) which confirmed the beneficial effect of application of $\mathrm{N}$ at reproductive stage of rice as observed in the present study. Fageria (2014) stated that variation in grain yield due to $\mathrm{N}$ uptake in grain and shoot was 70 and $47 \%$, respectively. This means that $\mathrm{N}$ uptake in grain has higher correlation with grain yield compared to shoot. Consequently, better capability of landrace Kutiagni to uptake higher amount of $\mathrm{N}$ in grain and total $\mathrm{N}$ in plant prepared itself outstanding to increase grain yield under unfavorable lowland ecosystem.

Shoot biomass yield at heading showed a linear relationship with grain yield (Figure 1) of all rice cultivars. Hence, increasing shoot dry weight can increase grain yield. Other authors (Peng et al., 2000; Fageria and Barbosa, 2001) also reported that grain yield of lowland rice increased significantly with increasing shoot dry weight.

Table 3. Effect of $\mathrm{N}$ fertilization on grain and straw yield of landrace rice cultivars

\begin{tabular}{|c|c|c|c|c|c|c|c|c|c|}
\hline \multirow{2}{*}{$\begin{array}{l}\text { Nitrogen } \\
\text { fertilization }\end{array}$} & \multicolumn{3}{|c|}{ Grains $\mathrm{N}$ uptake $\left(\mathrm{kg} \mathrm{ha}^{-1}\right)$} & \multicolumn{3}{|c|}{ Total N uptake $\left(\mathrm{kg} \mathrm{ha}^{-1}\right)$} & \multicolumn{3}{|c|}{$\mathrm{N}$ harvest index $(\%)$} \\
\hline & $\begin{array}{l}\text { Raja } \\
\text { shail }\end{array}$ & $\begin{array}{c}\text { Kuti } \\
\text { agni }\end{array}$ & $\begin{array}{l}\text { Sada } \\
\text { mota }\end{array}$ & $\begin{array}{l}\text { Raja } \\
\text { shail }\end{array}$ & $\begin{array}{l}\text { Kuti } \\
\text { agni }\end{array}$ & $\begin{array}{l}\text { Sada } \\
\text { mota }\end{array}$ & $\begin{array}{l}\text { Raja } \\
\text { shail }\end{array}$ & $\begin{array}{l}\text { Kuti } \\
\text { agni }\end{array}$ & $\begin{array}{l}\text { Sada } \\
\text { mota }\end{array}$ \\
\hline Two splits of PU & 27.15 & 32.54 & 31.46 & 50.90 & 59.51 & 56.65 & 53.58 & 54.71 & 55.60 \\
\hline DPUSG at 10 DAT & 25.86 & 27.44 & 27.28 & 45.55 & 53.73 & 49.50 & 56.71 & 50.05 & 48.46 \\
\hline DPUSG before PI & 31.41 & 36.08 & 29.72 & 56.25 & 60.05 & 53.67 & 55.48 & 60.31 & 54.65 \\
\hline PU before PI & 27.27 & 30.79 & 31.55 & 46.92 & 56.17 & 57.08 & 58.71 & 54.90 & 55.55 \\
\hline No urea & 25.52 & 26.78 & 23.76 & 42.55 & 46.92 & 46.68 & 60.00 & 58.52 & 58.95 \\
\hline $\mathrm{LSD}_{0.05}$ for $\mathrm{N}$ & NS & 3.83 & 6.79 & 8.89 & 7.38 & NS & NS & 5.54 & 9.03 \\
\hline $\mathrm{N} \times$ Variety & & 5.29 & & & 9.61 & & & 10.77 & \\
\hline $\mathrm{CV}(\%)$ & & 10.7 & & & 10.8 & & & 11.4 & \\
\hline
\end{tabular}

PU = Prilled urea, DPUSG = deep placement of urea super granule, DAT = Days after transplanting, $\mathrm{PI}=$ Panicle initiation and NS $=$ Not significant 


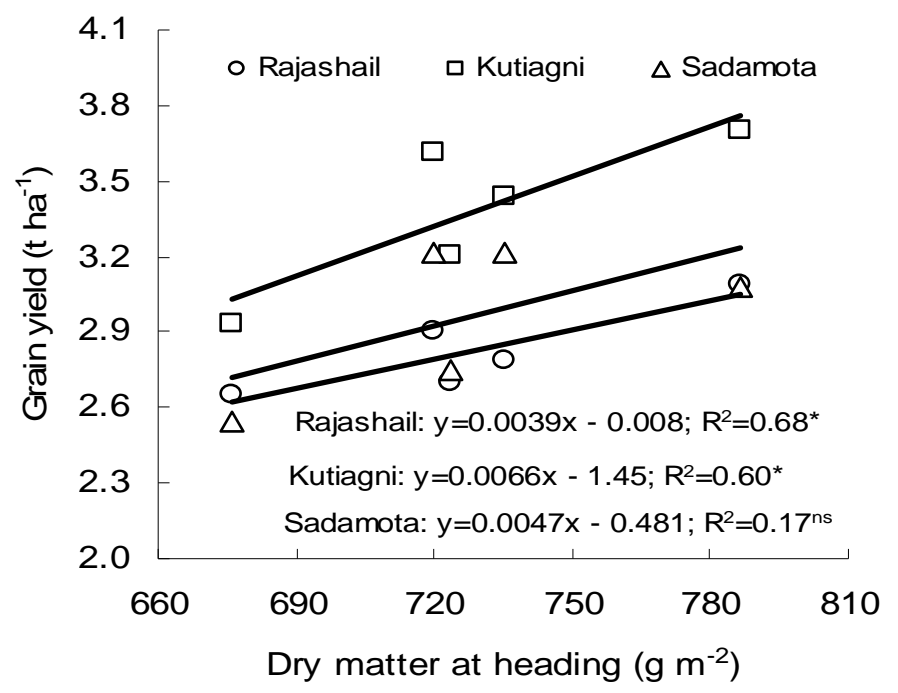

Figure 1. Relationship between dry matter production at heading and grain yield of Aman rice; * and NS = significant at 5\% level and not significant, respectively.

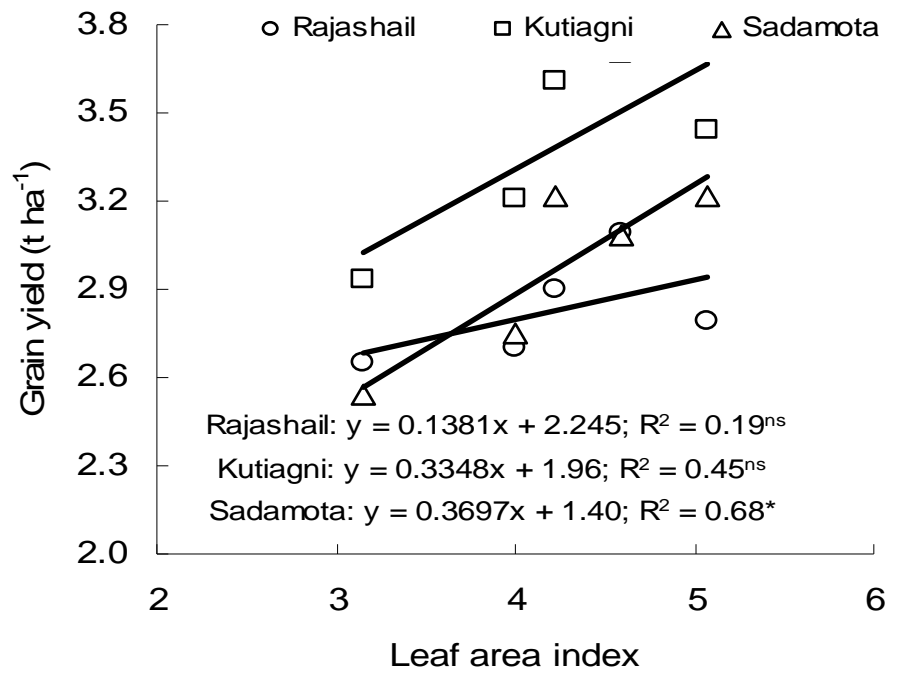

Figure 2. Relationship between leaf area index and grain yield of Aman rice; * and NS = significant at 5\% level and not significant, respectively.

There was a significant linear relationship between leaf area index (LAI) and grain yield (Figure 2) in all tested cultivars. However, the relationship was significant in case of Sadamota $\left(\mathrm{R}^{2}=0.68^{*}\right)$ but not for Rajashail and Kutiagni (Table 4). 
The grain yield had a linear association with grain $\mathrm{N}$ content in all cultivars (Figure 3 ). All the significant relationships indicated that grain yield increases with increasing of grain $\mathrm{N}$ absorption. The accumulation of $\mathrm{N}$ in grain accounted 85, 95 and $66 \%$ variation for Rajashail, Kutiagni and Sadamota, respectively
(Table 4). The relationships were $\mathrm{y}=0.058 \mathrm{x}+$ $1.129, \mathrm{R}^{2}=0.85^{* *}$ for Rajashail; $\mathrm{y}=0.1078 \mathrm{x}+$ $0.25, R^{2}=0.95^{* *}$ for Kutiagni and $y=0.0926 x+$ $0.2785, \mathrm{R}^{2}=0.66 *$ for Sadamota. Fageria (2014) reported that variation in grain yield due to $\mathrm{N}$ uptake in grain and shoot was 70 and $47 \%$, respectively.

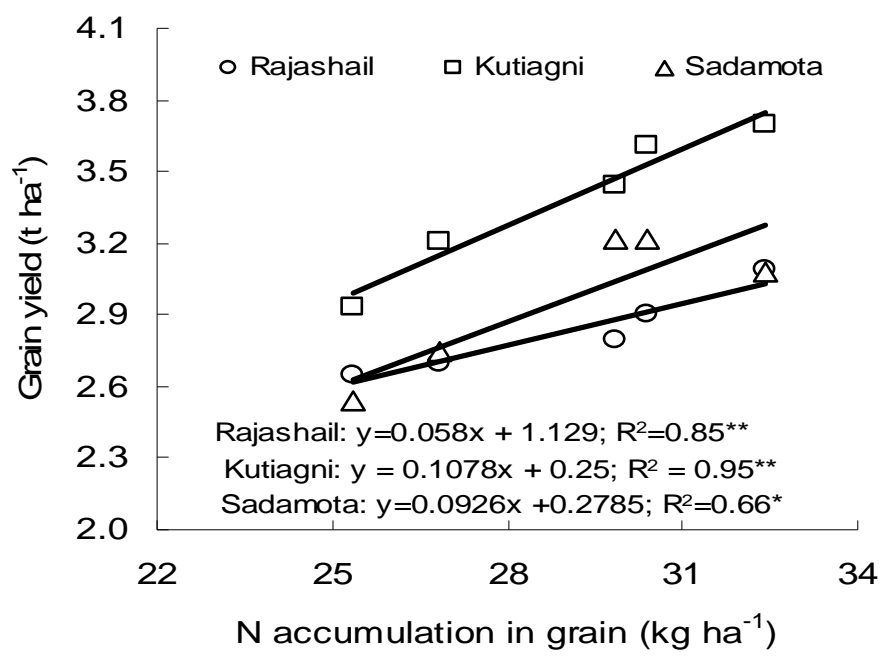

Figure 3. Relationship between grain $\mathrm{N}$ accumulation and grain yield of Aman rice; $*$ and ${ }^{* *}=$ significant at 5 and $1 \%$ level, respectively.

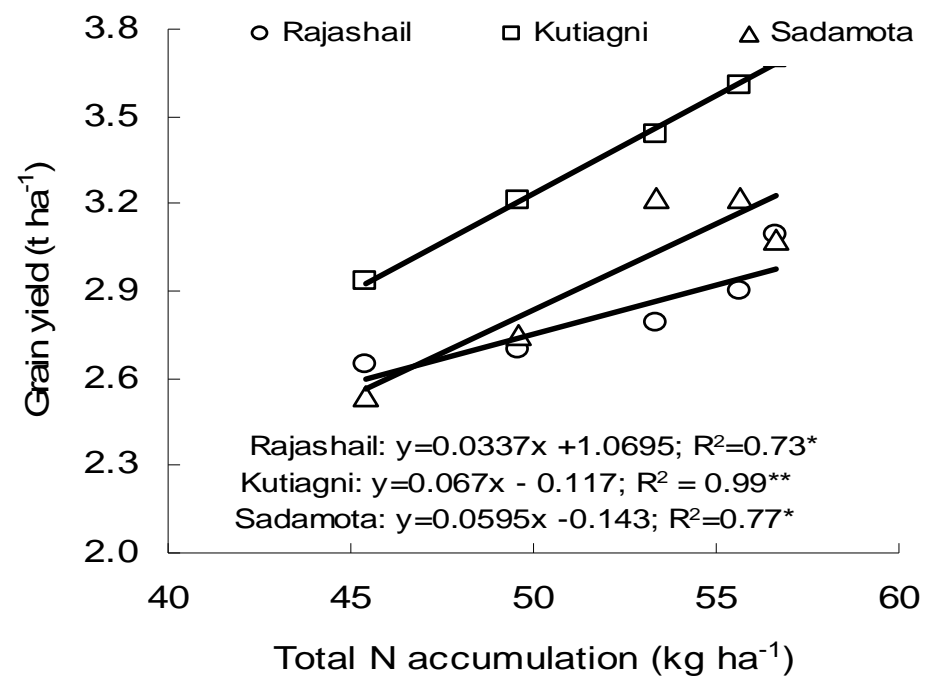

Figure 4. Relationship between total $\mathrm{N}$ accumulation and grain yield of Aman rice; $*$ and $* *=$ significant at 5 and $1 \%$ level, respectively. 
Table 4. Associations of grain yield with different growth parameters and $\mathrm{N}$ content of landrace rice cultivars

\begin{tabular}{llccc}
\hline Variables & Cultivars & Adjusted $\mathrm{R}^{2}$ & F-value & Probability level \\
\hline Dry matter production at heading & Rajashail & $0.69^{*}$ & 9.70 & 0.05 \\
vs. grain yield of landrace rice & Kutiagni & $0.60^{*}$ & 7.02 & 0.05 \\
cultivars & Sadamota & $0.17^{\mathrm{ns}}$ & 1.81 & 0.27 \\
\hline Leaf area index at heading vs. grain & Rajashail & $0.19^{\mathrm{ns}}$ & 1.41 & 0.32 \\
yield of landrace rice cultivars & Kutiagni & $0.45^{\mathrm{ns}}$ & 4.23 & 0.12 \\
& Sadamota & $0.68^{*}$ & 9.75 & 0.05 \\
\hline $\mathrm{N}$ accumulation in grain vs. grain & Rajashail & $0.85^{* *}$ & 25.02 & 0.01 \\
yield of landrace rice cultivars & Kutiagni & $0.95^{* *}$ & 66.07 & 0.01 \\
& Sadamota & $0.66^{*}$ & 8.75 & 0.05 \\
\hline Total N accumulation vs. grain & Rajashail & $0.73^{*}$ & 11.82 & 0.05 \\
yield of landrace rice cultivars & Kutiagni & $0.99^{* *}$ & 1284 & 0.01 \\
& Sadamota & $0.77^{*}$ & 14.70 & 0.05 \\
\hline
\end{tabular}

$*, * *$ and NS $=$ significant at 5 and $1 \%$ level; and not significant, respectively.

There was a significant linear relationship between total $\mathrm{N}$ absorption and grain yield in all cultivars (Figure 4). However, the relationships were significant for all cultivars. The relationships were $\mathrm{y}=0.0337 \mathrm{x}+1.0695, \mathrm{R}^{2}=$ $0.73 *$ for Rajashail; $\mathrm{y}=0.067 \mathrm{x}-0.117, \mathrm{R}^{2}=$ $0.99 * *$ for Kutiagni and $\mathrm{y}=0.0595 \mathrm{x}-0.143, \mathrm{R}^{2}$ $=0.77 * *$ for Sadamota (Table 4).

\section{Economic analysis}

Rajashail produced $440 \mathrm{~kg}$ more grains $\mathrm{ha}^{-1}$ in DPUSG before PI (Table 5). On the other hand, Kutiagni and Sadamota gave yield advantage of $680 \mathrm{~kg} \mathrm{ha}^{-1}$ in two splits of PU. However, 770 and $540 \mathrm{~kg}$ more grains $\mathrm{ha}^{-1}$ was recorded from Kutiagni and Sadamota in DPUSG before PI. Application of PU before PI also gave yield advantage by more than $500 \mathrm{~kg} \mathrm{ha}^{-1}$ in Kutiagni and Sadamota. Hence, maximum gross margin was obtained from Rajashail and Kutiagni with DPUSG before PI. However, Sadamota gave maximum gross margin in both two splits of PU and PU before PI (Table 6).

Moreover, application of DPUSG before PI gave maximum gross margin but it needed higher fertilizer cost than other treatments (Table 6). Lower fertilizer cost was involved in application of PU before PI treatment. Therefore, maximum profit was obtained from Sadamota in PU before
PI (Table 6). However, Rajashail and Kutiagni gave maximum profit in DPUSG before PI. Though DPUSG in rice required more labor cost compared to broadcasting of prilled urea (PU) or control, but it increased grain yield and farm profit (Tables 5 and 6). The DPUSG involved more cost compared to PU or control was welldocumented by many previous studies conducted in Bangladesh (Gregory et al., 2010; Miah et al., 2016). The DPUSG was done by hand and the cost of fertilizer includes the cost of purchasing $\mathrm{N}$ and application cost. Other intercultural practices such as transplanting, gap filling, weeding, harvesting, etc. were considered equally for all treatments. The cost for DPUSG varies location to location depending on the working efficiency of the labors (Thompson and Sanabria, 2010).

Therefore, difference in fertilizer cost including its application was considered for economic comparison. Net profit was calculated as the profit difference between DPUSG yield and no urea applied plot. The local market prices of nitrogen fertilizer and rice were considered. The study confirmed that yield response and gross margin was higher in DPUSG before PI treatment plot (Table 5 and Table 6). Maximum profit was obtained from DPUSG before PI in case of Rajashail and Kutiagni. 
Table 5. Yield response to $\mathrm{N}$ fertilization and gross margin of landrace rice cultivars

\begin{tabular}{|c|c|c|c|c|c|c|}
\hline \multirow{2}{*}{$\begin{array}{l}\text { Nitrogen } \\
\text { fertilization }\end{array}$} & \multicolumn{3}{|c|}{$\Delta$ Grain yield $\left(\mathrm{kg} \mathrm{ha}^{-1}\right)$} & \multicolumn{3}{|c|}{ Gross margin ( BDT ha $^{-1}$ ) } \\
\hline & Rajashail & Kutiagni & Sadamota & Rajashail & Kutiagni & Sadamota \\
\hline Two splits of PU & 250 & 680 & 680 & 3750 & 10200 & 10200 \\
\hline DPUSG at 10 DAT & 50 & 280 & 210 & 750 & 4200 & 3150 \\
\hline DPUSG before PI & 440 & 770 & 540 & 6600 & 11550 & 8100 \\
\hline PU before PI & 140 & 510 & 680 & 2100 & 7650 & 10200 \\
\hline $\mathrm{LSD}_{0.05}$ & NS & 219 & NS & NS & 3287 & 6121 \\
\hline CV (\%) & 33.5 & 19.7 & 38.3 & 27.3 & 19.7 & 38.8 \\
\hline
\end{tabular}

PU = Prilled urea; DPUSG = deep placement of urea super granule; DAT = Days after transplanting; $\mathrm{PI}=$ Panicle initiation; Price of rice $=15.0 \mathrm{BDT} \mathrm{kg}{ }^{-1}$; BDT $=$ Bangladeshi Taka .

Table 6. Cost and profit due to $\mathrm{N}$ fertilization in landrace rice cultivars

\begin{tabular}{|c|c|c|c|c|c|c|}
\hline \multirow{2}{*}{$\begin{array}{l}\text { Nitrogen } \\
\text { fertilization }\end{array}$} & \multirow{2}{*}{$\begin{array}{l}\text { Price of N } \\
\left(\text { BDT kg }^{-1}\right)\end{array}$} & \multirow{2}{*}{$\begin{array}{l}\text { Labors } \\
\left(\text { no. } \text { ha }^{-1}\right)\end{array}$} & \multirow{2}{*}{$\begin{array}{l}\text { Total cost for } \\
N\left(\text { BDT ha }^{-1}\right)\end{array}$} & \multicolumn{3}{|c|}{ Profit over $\mathrm{N}$ cost $\left(\mathrm{BDT} \mathrm{ha}^{-1}\right)$} \\
\hline & & & & Rajashail & Kutiagni & Sadamota \\
\hline Two splits of PU & 34.72 & 4 & 2442 & 1308 & 7758 & 7758 \\
\hline DPUSG at 10 DAT & 47.74 & 3 & 2482 & -1732 & 1718 & 668 \\
\hline DPUSG before PI & 47.74 & 4 & 2832 & 3768 & 8718 & 5268 \\
\hline PU before PI & 34.72 & 3 & 2092 & 8 & 5558 & 8108 \\
\hline $\mathrm{LSD}_{0.05}$ & & & & NS & 3011 & 6050 \\
\hline $\mathrm{CV}(\%)$ & & & & 88.3 & 21.2 & 45.5 \\
\hline
\end{tabular}

$\mathrm{PU}=$ Prilled urea; DPUSG = deep placement of urea super granule; DAT = Days after transplanting; $\mathrm{PI}=$ Panicle initiation; $\mathrm{BDT}=$ Bangladeshi Taka, Amount of $\mathrm{N}$ applied $=30 \mathrm{~kg} \mathrm{ha}^{-1}$; labor cost $=350.0$ BDT man-day ${ }^{-1}$.

However, Sadamota gave maximum profit in PU before PI. Application of DPUSG at 10 DAT failed to give better yield, gross margin and profit in all varieties. Miah et al. (2016) and Mamun et al. (2017) also stated that DPUSG increased grain yield and provided higher economic return in rice cultivation during Aman season.

\section{Conclusions}

Rajashail, Kutiagni and Sadamota are very popular landrace rice cultivars for Aman season and $\mathrm{N}$ deficiency is one of the most yield limiting factors for this crop in southern region of Bangladesh. This study showed that application of $\mathrm{N}$ fertilizer significantly increased tiller production, leaf area index, dry matter, panicle production and $\mathrm{N}$ accumulation in grains resulting in improved grain yields. These results revealed that the landrace rice cultivar Kutiagni was responsive to applied N. More than half ton yield advantage might be obtained through DPUSG before PI stage of landraces Aman rice cultivar Kutiagni that added farm income up to $8718 \mathrm{BDT} \mathrm{ha}^{-1}$. It may be concluded that landrace rice cultivar Kutigani could be cultivated with the application of DPUSG at PI stage.

\section{Acknowledgement}

The research was supported by United States Agency for International Development (USAID) funded project "Extension of Cereal System Initiative for South Asia (CSISA) in Bangladesh" led by International Rice Research Institute (IRRI) and executed by Agronomy Division of Bangladesh Rice Research Institute (BRRI), PLA ID. C-2012-488 and DRPC Ref. No. DRPC2010-66. 


\section{References}

Abedin SMS., Mannan MA., Mamun MAA., Rahman GKMM., Mridha AJ. 2015. Growth and yield performance of tidal local Aman rice as influenced by USG application at non-tidal condition. Bangladesh Agronomy Journal, 18(1): 7180.

Bah A., Syed Omar SR., Anuar AR., Husni MHA. 2009. Critical time of nitrogen application during panicle initiation on the yield of two Malaysian rice cultivars (Oryza sativa L.). Pertanika Journal of Tropical Agricultural Science, 32 (2): 317-322.

Bandaogo A., Bidjokazo F., Youl S., Safo E., Abaidoo R., Andrews O. 2015. Effect of fertilizer deep placement with urea supergranule on nitrogen use efficiency in Sourou Valley (Burkina Faso). Nutrient Cycling in Agroecosystems, 102:79-89. doi:10.1007/s10705-014-9653-6.

BBS (Bangladesh Bureau of Statistics). 2015. Yearbook of Agricultural Statistics of Bangladesh. Bangladesh Bureau of Statistics, Stat. Div., Ministry of planning, Dhaka, Bangladesh, pp. 100-300.

Bhuiyan NI., Paul DNR., Jabbar MA. 2002. Feeding the extra million by 2025 . Challenges for rice research and extension in Bangladesh. Paper presented in the national workshop on research and extension, 29-31 January 2002. Bangladesh Rice Research Institute, Gazipur.

Castillo EG., Buresh RJ., Ingram KT. 1992. Lowland rice yield as affected by timing of water deficit and nitrogen fertilization. Agronomy Journal, 84: 152-159.

Chaturvedi I. 2005. Effect of nitrogen fertilizers on growth, yield and quality of hybrid rice. Journal of Central European Agriculture, 6:611-618.
Dobermann A., Fairhast T. 2000. Rice: Nutrient disorders and nutrient management. Oxford Graphic Printers Pte Ltd. pp. 1191.

Dobermann A., Witt C, Dawe D., Abdulrachman S., Gines HC., Nagarajan R., Satawathananont S., Son TT., Tan C.S., Wang GH., Chien NV., Thoa VTK., Phung CV., Stalin P., Muthukrishnan P., Ravi V., Babu M., Chatuporn S., Sookthongsa J., Sun Q., Fu R., Simbahan G.C., Adviento MAA. 2002. Site-specific nutrient management for intensive rice cropping systems in Asia. Field Crops Research, 74:37-66.

FAO (Food and Agriculture Organization). 2016. Production, international trade, rice utilization and domestic price. Rice Market Monitor, 19(1):1-2.

Fageria NK., Baligar VC. 1999. Yield and yield components of lowland rice as influenced by timing of nitrogen fertilization. Journal of Plant Nutrition, 22:23-32.

Fageria NK., Barbosa MP. 2001. Nitrogen use efficiency in lowland rice genotypes. Communications in Soil Science and Plant Analysis, 32:2079-2089.

Fageria NK., Baligar VC., Clark RB. 2006. Physiology of crop production. New York: The Haworth Press.

Fageria NK., Morais OP., Santos AB. 2010. Nitrogen use efficiency in upland rice genotypes. Journal of Plant Nutrition, 33:1696-1711.

Fageria NK. 2014. Nitrogen harvest index and its association with crop yields. Journal of Plant Nutrition, 37:795-810.

Gomez KA., Gomez AA. 1984. Statistical Procedure for Agricultural Research $\left(2^{\text {nd }}\right.$ ed.). John Willey and Sons, Singapore. pp. 28-192. 
Gregory DI., Haefele SM., Buresh RJ., Singh U. 2010. Fertilizer use, markets, and management. In: S. Pandey et al., editors, Rice in the global economy: Strategic research and policy issues for food security. Int. Rice Research Inst., Los Baños, Laguna, Philippines.p. 231-263.

Hamid A., Haque MM., Karim MA., Badsha MA. 2004. Variation in phasic photosynthesis and productivity of indigenous rice cultivars. Bangladesh Agronomy Journal, 10:1-5.

IRRI (International Rice Research Institute). 2007. Crop Stat, version 7.2. Biometric unit of International Rice Research Institute, Los Banos, Philippines.

IRRI (International Rice Research Institute). 2013. Trends in global rice consumption. Rice Today 12 (1): 44-45.

IFDC (International Fertilizer Development Center). 2013. Fertilizer deep placement. IFDC solutions. Int. Fertilizer Development Center, Muscle Shoals, AL. http://issuu.com/ifdcinfo/docs/fdp_8pg_fi nal_web? e= $1773260 / 1756718$, retrieved date on 25 March 2018.

Lin X., Zhou W., Zhu D., Chen H., Zhang Y. 2006. Nitrogen accumulation, remobilization and partitioning in rice (Oryza sativa L.) under an improved irrigation practice. Field Crops Research, $96: 448-454$.

Mamun MAA., Haque MM., Khaliq QA., Karim MA., Karim AJMS., Mridha AJ., Saleque MA. 2015. Assessment of soil chemical properties and rice yield in tidal submergence ecosystem. Bangladesh Agronomy Journal, 18(2):79-87.

Mamun MAA., Haque MM., Khaliq QA., Karim MA., Karim AJMS., Mridha AJ., Saleque MA. 2016. Yield and nitrogen use efficiency of locally improved rice varieties in rice based tidal flooded ecosystem of Bangladesh. Bangladesh Agronomy Journal, 19(2):39-49.

Mamun MAA., Haque MM., Saleque MA., Khaliq QA., Karim MA., Karim AJMS. 2017. Nitrogen fertilizer management for tidal submergence tolerant landrace rice (Oryza sativa L) cultivars. Annals of Agricultural Science, 62(2):193-203.

Miah MAM., Gaihre YK., Hunter G., Singh U., Hossain SA. 2016. Fertilizer deep placement increases rice production: evidence from farmers' fields in southern Bangladesh Agronomy Journal, 108(2): 18.

Peng S., Laza RC., Visperas RS., Sanico AL., Cassman KG., Khush GS. 2000. Grain yield of rice cultivars and lines in the Philippines since 1966. Crop Science, 40: 307-314.

Rochette P., Angers DA., Chantigny MH., Gasser MO., Mac-Donald JD., Pelster DE., Bertrand N. 2013. Ammonia volatilization and nitrogen retention: How deep to incorporate urea? Journal of Environmental Quality, 42: 1635-1642. doi:10.2134/jeq2013.05.0192.

Thompson TP., Sanabria J. 2010. The division of labor and agricultural innovation in Bangladesh: Dimension of gender. Int. Fertilizer Development Center, Muscle Shoals, AL

Tylaran RD., Ozawa S., Miyamoto N., Ookawa T., Motobayashi T., Hirasawa T. 2009. Performance of a high-yielding modern rice cultivar Takanari and several old and new cultivars grown with and without chemical fertilizer in a submerged paddy field. Plant Production Science, 12: 365380 . 